\title{
Bir Anne-Oğul Mücadelesi: Kevin Hakkında Konuşmalıyız Filminin Analizi
}

\author{
Uzm. Bermal AYDIN \\ Yrd. Doç. Dr. Filiz BiLGiN ÜLKEN
}

mersin üniversitesi iletişim fakültesi radyo, televizyon ve sinema bölümü

bermal.aydin@gmail.com filizbilgin77@gmail.com

\begin{abstract}
The Mother and Son Struggle: The Analysis of "We Need To Talk About Kevin"

Mainstream movies reproduce current patriarchal structure and dominant norm patterns.But even if rarely there are movies that stay outside the hegemonic gender roles or at least exhibit a neutral stance. The film of this study We Need to Talk About Kevin (Lynne Ramsay, 2011) which is an adaptaion of Lionel Shriver's novel, asks bold questions about gender roles and the tasks attributed to women and men. The film doesn't impose any idea and not declare a guilty. The main purpose and problematic of this study is making clear that the film is positioned outside the mainstream movies through the way it handles the issues on family, motherhood, mother-child relationship that attributed with almost sacred values in the modern society. For this purpose and problematic hidden meanings in the film are being exposed through the method of semiotic analysis.
\end{abstract}

keywords: gender, family, femininity, motherhood, mother-child relationship 


\section{Résumé}

\section{Kévin»}

\section{Une lutte entre mère et fils : L'analyse du film « II faut qu'on parle de}

Les films grand public reproduisent la société patriarcale et ses normes dominantes, Mais même rarement, il y a des films qui se placent en dehors des stéréotypes de genre ou bien portent un œil neutre. Dans cette étude, "I faut qu'on parle de Kévin " (Lynne Ramsay, 2011)adapté du roman de Lionel Shrivel au cinéma est un exemple de ce type de film ayant un regard neuf sur la question de la division du sexe, de la féminité et de la masculinité. Le film se différencie des autres puisqu'il n'impose aucune idée reçue et ni ne cherche un coupable. L'objectif principal et le problématique de cette étude sont de montrer comment le film est placé en dehors des films à grand public et comment il représente les questions de famille, de maternité, de relation mère-enfant auxquelles la société dominante attribue des valeurs presque sacrées. L'analyse sémiotique est utilisée pour mettre l'accent sur les significations latentes du film. enfant

mots-clés : le genre, la famille, la féminité, la maternité, la relation mère-

\section{Özet}

Ana akım filmler ataerkil yapıyı ve onun egemen normlarını yeniden üretirler. Ancak nadiren de olsa hegemonik cinsiyet kalıplarının dışında yer alan ya da en azından tarafsız bir duruş sergileyen filmler de vardır. Bu çalışmanın konusu olan ve Lionel Shriver'ın aynı adlı romanından beyazperdeye uyarlanan Kevin Hakkında Konuşmalıyız (We Need to Talk About Kevin, Lynne Ramsay, 2011) adlı film, toplumsal cinsiyet rolleri ve kadın ile erkeğe yüklenen görevlerle ilgili sorular sormaktadır. Bunu yaparken ise film, hiçbir fikri empoze etmeye çalışmaz veya bir suçlu ilan etmez. Bu çalışmanın temel amacı ve sorunsalı, filmin, modern toplumda neredeyse kutsal değerler atfedilen aile, annelik, anne-çocuk ilişkisi gibi meseleleri ele alış biçimiyle, ana akım filmlerden nasıl ayrı durduğunu göstermektir. Filmdeki saklı anlamlar göstergebilimsel analiz yönteminden yararlanılarak ortaya çıkarılmaya çalışılmaktadır.

anahtar kelimeler: Toplumsal cinsiyet, aile, kadınlık, annelik, anne-çocuk ilişkisi 


\section{Giriş}

Hollywood tür filmleri, hâkim söylem ve ideolojileri yineleme ve böylelikle yeniden üretme yolunda bir işlev görürken; bağımsız ya da alternatif sinema, hegemonik temsillerin, bakış açılarının karşısında konumlanır ve bunları sorgular. Lionel Shriver'ın aynı adlı romanından sinemaya uyarlanan We Need to Talk About Kevin (Kevin Hakkında Konuşmalıyız, Lynne Ramsay, 2011) adlı filmin incelemek için seçilmesinin nedenleri şöyle açıklanabilir: Film, özellikle kapitalist eril ideolojide kabul gören toplumsal cinsiyet rollerini, kadından üstlenmesi beklenen annelik görev ve sorumluluklarını sorgulamakta, anneliğin kadının kendisine biçilen cinsiyet rolünün doğal bir uzantısı olup olmadığını tartışmaya açmaktadır.

Pek çok ana akım film, ahlaki, siyasi, ekonomik ve toplumsal cinsiyet gibi farklı bağlamlarda statükoyu destekleme ve yeniden üretme işlevi görürken; alternatif, deneysel ya da bağımsız sinema, ana akım sinema içinde yer alan baskın gerçekçilik konumuna belirli yollarla meydan okur. Dünyayı daha eleştirel gözlerle görmemizi engelleyen algısal ve bilişsel sistemleri sorgular. Ana akım sinema genellikle bir izleyici kitlesini mutlu etmek üzere tasarlanmış, kahramanlık mitine dayalı, iyi-kötü ikiliğine yaslanan ve kötü karakterin bedel ödemesi, iyi karakterin hedefine ulaşması gibi uylaşımları destekleyen bir yapıya sahiptir.

\footnotetext{
"İzleyici bir filmi izledikten sonra dünyanın sadece mevcut haliyle var olabileceğini, 'gerçek' olduğunu ve bu nedenle de kalıcı ve sorgulanamaz olduğunu hisseder. Sadece 'gerçekliğin' alanı içinde cereyan eden aksiyonu göstererek bile, ana akım anlatı sineması yaşanılan dünyaya, hak etmediği sorgulanamazlık niteliği atfeder. (...) Alternatif sinema... ana akım anlatı sineması içinde normal olarak yapılanan sinemasal gerçekliği sarsarak gerçekliğe ilişkin kesinlik duygusunu alt üst eder. (... ) Uylaşımları ve basmakalıp yapıları sadece onları yıkmak ve bu uylaşımların ve yapıların genelde sağladığı rahatlık ve kesinlik duygusunu kırmak için kullanıı" (Ryan ve Lenos 2012: 176-179).
}

Ana akım sinema içerisinde bir kesinlik ve sarsılmazlık duygusuyla adeta doğal atfedilen toplumsal cinsiyet kabullerinde kadına düşenleri sorgulayan Kevin Hakkında Konuşmalıyız, alışılagelmiş uylaşımlara bağlı olarak bir suçlu, kurban ya da kahraman arayan seyirciye istediğini vermez ve onun rahatlık ile kesinlik beklentisini yıkar. Bu bağlamda alternatif sinemaya yakın duran filmin, modern toplumun ideolojik itici gücü olan ailenin, egemen toplumsal cinsiyet tanımları çerçevesinde kadına ve erkeğe yüklenen görevlerin, anneliğin, anne-çocuk ilişkisinin, bir çocuğun suça bulaşmasında ailenin, özellikle de annenin rolünün ne olduğuna dair sorgulamaları nasıl ele aldığını ortaya çıkarmak bu çalışmanın amacını oluşturmaktadır.

Bu amaç doğrultusunda göstergebilimsel analiz yönteminden yararlanılarak filmdeki saklı ya da açık anlamlar, temsillere, imgelere ve simgelere bakılarak açığa çıkarılmaya çalışımıştır. Anlam üretiminin analiz edilmesine dayanan ve bunu bir 
metindeki göstergelerden yola çıkıp göstergenin temel ve/veya yan anlamı olan gösterileni açığa çıkarmaya çalışarak yapan göstergebilimsel yaklaşım, sinema söz konusu olduğunda görüntüsel ve dilsel göstergelerin yanı sıra simgesel göstergeleri de çözümlemeye dâhil eder (Kabadayı 2014: 65-67).

Yapılan filmsel çözümlemede göstergebilimin yanı sıra, toplumsal cinsiyet ve psikanaliz yaklaşımından da yararlanılmıştır. İdeolojik ve kültürel olarak yapılandırımış olan toplumsal cinsiyet, kadın ve erkek arasındaki biyolojik farklardan yola çıkarak onları davranışlar, değerler, tutumlar ve inançlar açısından da kategorize etmeyi ve eşit olmayan biçimde ayrıştırmayı ifade eder. Psikanaliz ise filmdeki ataerkil bilinçdışı yapılanmaları açıklaması açısından önemlidir (Kabadayı 2014: 75-92). Benliğin oluşumunda anne-çocuk-baba üçgenini temeline alan Oedipus karmaşası, film anlatısındaki anne-çocuk ilişkisini kavramak adına bir izlek oluştururken; toplumsal cinsiyet normlarında kadından beklenen görevler ile "iyi anne" algısının dönemlere ve koşullara göre dönüşümüne bakmak da, filmdeki kadının yaşadığı annelik krizini anlayabilmek için önemlidir. Çalışmanın önemi ise ana akımdan farklılaşan muhalif, bağımsız ve alternatif kültür ürünlerinin incelenmesinin, hem bu tarz ürünlerin bilinirliğinin artmasında, hem de gitgide birbirine benzeyen ürünlerle karşı karşıya kaldığımız küresel kültür çağında farklı seslerin de var olabileceğine dair bir umut olduğunu göstermesinde yatmaktadır.

\section{Hepimiz "Kevin ve Eva Hakkında Konuşmalıyız"}

Yönetmenliğini Lynne Ramsay'in üstlendiği Kevin Hakkında Konuşmalıyız (We Need To Talk About Kevin), aslında Kevin değil, Eva hakkında bir filmdir: 16 yaşındaki oğlu katliam yapan bir annenin ve anne-oğul arasında zaman zaman savaşa dönüşen uzaklığın hikâyesi. Filmde Kevin'ın (Jasper Newell, Rock Duer, Ezra Miller) gerçekleştirdiği katliamın öncesini ve sonrasını Eva'nın (Tilda Swinton) geçmişle bugün arasındaki gidiş gelişleriyle, Eva'nın anıları olarak görürüz. Filmdeki tüm olaylar Eva'nın bakış açısıyla ele alınmıştır ve filmin anlatısı Eva'nın belleğindeki anıları derleyip toplama biçimi üzerine kurulmuştur. Anlatı perspektifinin (Ryan ve Lenos 2012: 153) bu şekilde kuruluşu, Eva'nın çelişkilerini, duygularını, çatışmalarını anlamamızı kolaylaştııı; seyirciyi olayları onun gözüyle görmeye götürür. Yönetmen, bu bilinçli seçimiyle filminin merkezine kadını ve kadın bakışını koyarken; seyirciyi de Eva'yla özdeşleşmeye yönlendirmektedir. Kadın karakter için seçilen Eva isminin, Latin kökenli birçok dilde Havva anlamına geldiği düşünülürse, anlatılan öykünün tek bir kadın üzerinden tüm bir kadınlık durumunu sergileme iddiasında olduğu söylenebilir.

Seyahat yazıları yazan Eva'nın hayatı çocuk sahibi olduktan sonra tamamıyla değişir. Başlangıçta bir çocuk doğurmayı istemekle birlikte; hamilelik sürecindeki hoşnutsuz halinden ve bebek, yani Kevin doğduktan sonra yaşadığı sıkıntılardan dolayı, anneliğe gerçekten hazır olup olmadığını sorgular. Kocası Franklin'in (John C. Reilly), Kevin'a, Eva'ya ve anne oğul arasındaki ilişkiye iyi geleceğini düşünerek şehirden uzak, bahçeli bir yere taşınma ısrarı üzerine Eva, ayrılmak 
istemediği New York'tan banliyöye taşınır. Bu yeni hayatında arada kaçışları olsa da evden kurduğu bağlantılar dışında çalışamaz ve seyahat edemez. O zamana kadar alışık olduğu ve sevdiği her şeyden vazgeçmiş gibidir. Tüm bu değişimlerin üzerine bir de Kevin'ın "zor" bir çocuk olması eklenince Eva, gün geçtikçe daha depresif ve mutsuz hale gelir. Film boyunca Kevin ve Eva arasındaki gerilime tanık olunurken; filmde işaret edildiği şekilde annelik rolünü üstlenmekte güçlük çeken Eva'nın Kevin'la yakınlaşma çabalarının yanıtsız kaldığı görülür. Kevin'in psikolojik zorlamaları karşısında kimi zaman kendine hâkim olamayan Eva, bazen şiddete başvursa da genel olarak sabırlı bir tutum sergiler. Annesiyle ilişki kurmakta zorlanan Kevin, okulda bir gösteriye benzemesini istediği bir katliam gerçekleştirir. Okul arkadaşları da dahil birçok kişinin hayatına mal olan Kevin'in işlediği suçla birlikte Eva'nın yaşamı bir kez daha değişir. Kevin içeride, Eva dışarıda hapis hayatı yaşarken; anne oğlun kapatılmışlıkları arasındaki fark, Eva'nın kendi inşa ettiği hapishaneye mahkûm olmasıdır. Eva'nın bedel ödemek amacıyla hapsolduğu dünyayı izleyen seyirciyse, film boyunca Eva'nın deneyimine ortak olarak anneliği sorgular: Acaba, annelik gerçekten güdüsel midir? Kadın, doğurduğu çocuğu sever mi ve kendini doğal olarak çocuğuna yakın hisseder mi? Bir çocuk suç işlediğinde "anne" olmayı beceremediği söylenen kadını suçlu olarak kodlamak ne kadar doğrudur?

Film öznel kamera hareketiyle açılır: Perdeleri uçuşan açık balkon kapısına doğru kamerayı izleyen seyirci, Eva'nın kocası ve kızının cesetleriyle karşılaşmasına eşanlı olarak maruz kalır. Bu ilk sahne Eva'nın gözünden bir olaya tanık olacağımııı ipucunu verir. Ardından her yerin kıpkırmızı ve bedenlerin çıııçıplak olduğu sanısının egemen olduğu başka bir sahneye geçilir. Sahne ilerledikçe domates festivali olduğunu anladığımız bu görüntü, kadrajın tamamına hâkim olan kırmızı renk ve hareket halindeki insan bedenleriyle, toplu bir doğumu anımsatır. Eller üzerinde coşkulu bir şekilde giden Eva, filmin genelindeki mutsuz halinden oldukça uzaktır. Eva'nın kolları yana açık şekilde eller üstünde taşınması, İsa'nın çarmıha gerilme anlatısını ve kurban olma ritüelini anımsatır. Film, Eva'nın bir şeyin kurbanı olacağına dair bir beklenti ve endişe yaratır.

Fotoğraf 1-2: Domates Festivali ve Eva

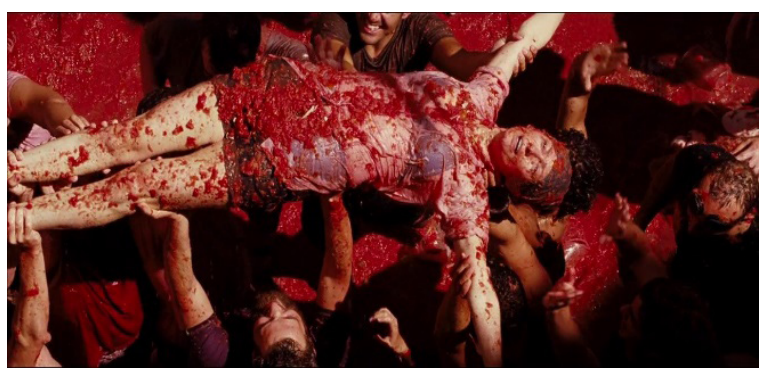




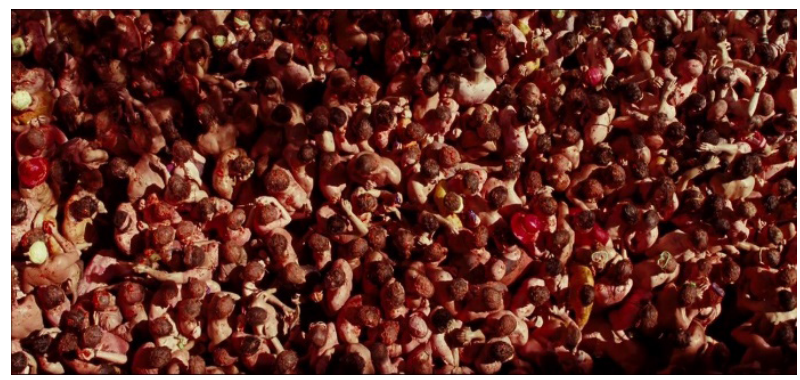

"Doğum: karmaşanın ve yaşamın doruğu, (içerisi/dışarısı, ben/öteki, hayat) ölüm) kararsızlığın can alıcı noktası, dehşet ve güzellik, cinsellik ve cinselliğin hoyrat yadsınışı" (Kristeva 2004: 212).

Kırmızı renk, film anlatısının tamamına hâkimdir ve filmin atmosferinin oluşturulmasında baskın olarak kullanılır. Domates festivalinin yanı sıra Eva'nın Kevin'la ilgili tüm anılarında ve şimdiki yaşamında kırmızının hâkimiyeti, belirgin şekilde öne çıkar. Eva'nın Kevin'a hamile kaldığı sevişme sahnesinin genel tonu, katliamın gerçekleştirildiği okulun spor salonunun kapısı, Eva'nın küçük Kevin'le oynamaya çalıştığı top, Kevin'in ekmeğin üzerine sürdüğü reçel, Eva'nın sürekli içtiği şarabın rengi kırmızıdır. Bunlar dışında Kevin'in Eva'nın haritalarla kapladığı odayı boyadığı renk, yılbaşı eğlencesinde Eva'nın giydiği elbise, Eva'nın kitabının imza günüyle ilgili afişin asıldığı duvar, afişe bakan Kevin'in giydiği mont, okul duvarındaki yazı (Expect Great Things - Büyük Şeyler Bekle) ile yazının üstüne yazııdığı duvarın rengi ve katliam günü okul önünün atmosferi kırmızıdır.

Renk kullanımı tüm filmlerde aynı anlama gelmese de Ryan ve Lenos'un Cinnet (Shining, 1980) filmindeki kırmızı renk kullanımıyla ilgili saptadığı gibi Kevin Hakkında Konuşmalıyız'da da kırmızı, " tehlikeli biçimde denetim altına alınamayan öfkeyi, bizi insan yapan medeni baskıları yerle bir etme tehlikesi bulunan doğayı, medeni baskılar yok olduğunda ortaya çıkan hayvani davranışları" (2012: 131) temsil etmektedir. Filmde kırmızının yoğun kullanımı, anne-oğul arasındaki bitmeyen savaşa, öfke ve şiddete olduğu kadar aralarındaki tutkulu bağlılı̆a da işaret eder gibidir.

Kırmızı renk kullanımıyla ilgili belirtilmesi gereken bir diğer nokta, filmde açıkça kimin yaptığı gösterilmeyen; ama, seyirciye ölen çocukların ailelerinin gerçekleştirmiş olabileceğini düşündüren Eva'nın katliamdan sonra yaşadığı evin ve kullandığı arabanın da kırmızıya boyanmış olmasıdır. Film boyunca evinden, arabasından, saçlarından ve ellerinden kırmızıyı temizlemeye uğraşan Eva, aslında kendisinin de sorumlu olduğunu düşündüğü katliamın anılarından ve suçluluk duygusundan arınmaya çalışır gibidir. Eva'nın, markette Kevin'in öldürdüğü çocuklardan birinin annesiyle karşılaşınca kırmızı konserve kutuları reyonuna saklanması da, bu suçluluk duygusunun dışavurumu olarak okunabilir. 


\section{Fotoğraf 3: Markette kırmızı konserve kutularının önündeki Eva}

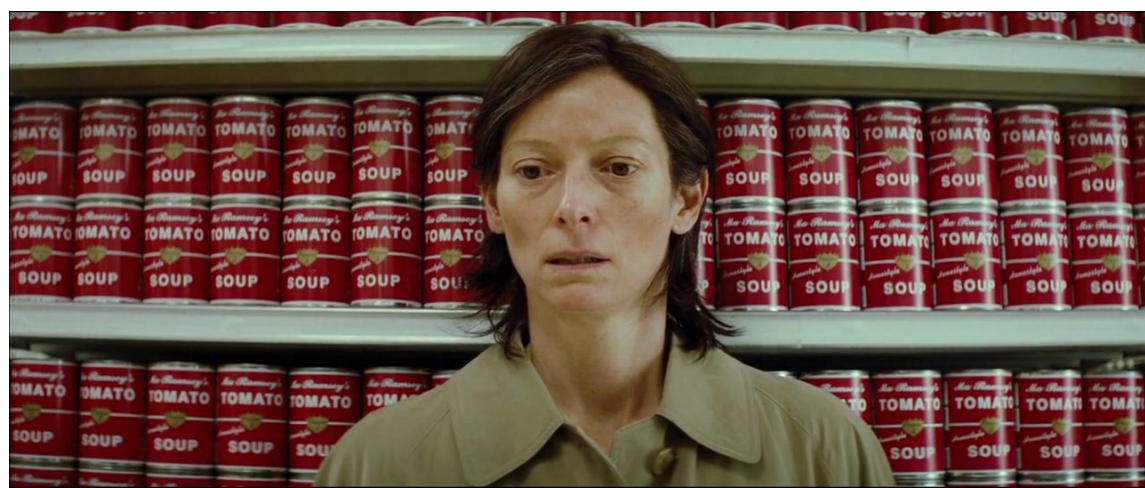

Katliamdan sonra taşındığı yeni evde kapısını çalan iki misyonerin "Öldükten sonra nereye gideceğinizi biliyor musunuz?" sorusu üzerine Eva'nın alaycı ve rahat bir şekilde verdiği cevap, Eva'nın Kevin'in işlediği suç için kendini sorumlu tuttuğuna işaret eder: "Oh, evet biliyorum. Doğrudan cehenneme gideceğim. Lanetlenmiş olarak sonsuza dek yanmaya".

Filmde Eva'nın Kevin'in işlediği suç yüzünden duyduğu vicdan azabına dair başka göstergeler de vardır: Evi ve arabası, çevre sakinlerince kırmızıya boyandığı halde bir tepki göstermez, Kevin'in öldürdüğü çocuklardan birinin annesi ona tokat attığında olayı görüp ona yardım etmek isteyen adama "Hayır, benim hatamdı" der, markette karşılaştığı kadın, Eva'nın aldığı yumurtaları kırdığında bunları değiştirmek yerine ısrarla kırık yumurtaları satın alır.

Eva'nın vicdan azabı hissetmesinde toplumun kadına, anne olmasından dolayı yüklediği sorumluluğun etkisi olduğunu söylemek gerekir. Kevin, bebekken ağladığında çevredeki kadınlar çocuğunu susturamayan Eva'ya suçlayan bakışlarla bakarlar, katliamda çocuğu ölen kadınların birçoğu, olaydan Eva'yı sorumlu tutar, Eva dışarı çıktığında kadın, erkek ya da çocuk herkesin suçlayan ve yargılayan bakışlarıyla karşılaşır. Bu yargılayan ve suçlayan toplumsal bakış, kadının "anne" olarak üstünde hissettiği baskının ağırlığına tanıklık eder. Bu baskı yüzünden dış dünya katliamın ardından Eva için baskıcı, kaotik ve ürkütücü bir hal alacaktır. Cadılar Bayramı'nda arabasıyla giderken yoldan geçen kostümlü ve makyajlı çocukların, yine kırmızı bir atmosfer içerisinde verilmesi, eve geldiğinde kapısını çalan ve şeker isteyen çocukların bağırışları karşısında Eva'nın mutfağın bir köşesine sinmesi, toplumu simgeleyen "dışarı"nın Eva için ürkütücü hale geldiğini göstermektedir. 


\section{Anneliğin Toplumsal Tarihi Bağlamında Eva'yı Düşünmek}

Kamusal ve özel alan ayrımının, kadın ve erkek ilişkilerine de yansıdığı 19. yüzyıl burjuva toplumunda kadın, özel alana hapsedilirken; kamusal alan erkeğin önceliğine bırakılmıştır. Kadınlığın, annelikle, anneliğin kadının doğasında olduğu varsayımıyla doğalmış gibi gösterilerek eşitlenmesi de bu ayrımın temelinde yer alır. Adrienne Rich, 1977 tarihli Of Woman Born adlı çalışmasında, annelik kurumunun toplumsal beklentiler, yasalar, kurallar ve kabullerden oluştuğunu öne sürer. Ona göre annelik kurumu, kültürel bir yapıdır ve Batı'da kültür gibi annelik de ataerkildir (akt. Porter 2010: 5). Ataerkil annelik kurumu, kadının, çocuğuyla ya da evliliğiyle ilgili herhangi bir olumsuz durumda suçlu ilan edilmesine, üstelik kadının da kendisini suçlamasına yol açar (Çeler 2013: 177).

O halde akıllara şu soru gelebilir: Anneliğin toplumsal algısı tarih boyunca böyle mi süregelmiştir? Bu sorunun cevabını Simone de Beauvoir, anneliğin ve kadınlığın doğal dürtülerle açıklanamayacak toplumsal ve kültürel bir kurgu olduğu, 1960'lar ve 1970'lerde ise Philippe Ariès, Edward Shorter ve Lawrence Stone gibi tarihçiler de, aile kurumunun, kadının ve çocuğun toplumsal algılanmasının tarihsel dönemlere ve sosyal koşullara göre değiştiği yönünde vermişlerdir (akt. Çeler 2103: 168). Hilde Lindemann Nelson'ın çalışması da, annelikle ilgili temel anlatıların ve iyi anne algısının tarihsel, toplumsal, kültürel ve ekonomik bağlama göre farklılaştığının altını çizmiştir (akt. Porter 2010: 7).

20. yüzyılın başında anneler, iyi anne olmak için kendilerini eğitebilecek donanıma sahip rasyonel ve yeterli insanlar olarak görülürdü. Yüzyılın ikinci ve üçüncü on yılında ise tıp ve psikoloji alanlarındaki gelişmelerin ve profesyonelleşmenin yükselişiyle anne, işinin ehli ve saygı duyulan kişiden tavsiye ve rehberlik için uzmanlara güvenmek zorunda olan itaatkâr, uyumlu anneye dönüşmüştür. $O$ yıllardan bugüne annelik tanımları, kadını evin içine kapamış ve çocuk bakımında kadını, doktorlara bağımlı hale getirirken, geçmiş bağımsızlık ihtimallerinin üzerini de örtmeyi inmal etmemiştir (Akşit Vural 2013: 185- 186; Porter 2010: 8-9).

II. Dünya Savaşı yıllarında erkeklerin büyük kısmı cepheye gittiği için kadınlar çalışmak durumunda kalmış, savaştan sonra ise kadınlardan yine evlerine ve ev işlerine dönmeleri beklenmiştir. II. Dünya Savaşı'nın ardından evine tekrar çağrılan kadının, sevecen anne ve ilgili eş olması gerekir. 1960'lı yılların feminist hareketleri ise kadının geleneksel cinsiyet rollerinin sorgulanmasını beraberinde getirmiş, annelik ve eşlik konumları yoğun olarak tartışımaya başlanmışıır. 1980'li yıllarda da feminist hareket toplumsal cinsiyet rolleri nedeniyle oluşan cinsiyet ayrımcılığını eleştirmeye devam etse de, neo-liberal muhafazakâr söylem kadının ev içi ve annelikle ilgili geleneksel ve doğal olduğu varsayılan rollerine yeniden meşru bir yaygınlık kazandırmıştır. 
Toplumsal gerçeklikte olduğu gibi film anlatısı içinde de babanın adeta "görünmez" olması semptomatiktir. Eva istemediği halde şehirden banliyöye taşınma ve boşanma gibi hayati konularda kararlar alan Franklin, kararlarına itaat edilmesini bekler ve Kevin-Eva mücadelesinde sorumluluğu Eva'ya yükleyerek anneyi çocukla baş başa bırakır. Baba, Eva ile Kevin arasında süregelen gerilime etkili bir şekilde müdahil olmazken, Eva'yı eleştiren sözlerinden Franklin'in aslında Eva'nın anneliğini sorguladığı ve yargıladığı anlaşıı. Franklin, çocuklarıyla eğlenceli vakit geçirirken onlarla ilgili problemli her durumdan uzak kalır ve üzerine düşen sorumluluğun farkına varamaz. Franklin, görülmediği kadar aynı zamanda görmeyen bir baba ve kocadır. Katliamın gerçekleştirileceği araçlar olan ok ve yay takımını Kevin'a Franklin alır, çünkü oğlunun "şiddete meylinin" farkında değildir. Çocukluğunda oyuncak ok ve yayla tanışan Kevin'a bir ergen olduğunda gerçek ok ve yay takımını alan da yine Franklin'dir. Ayrıca Franklin, Kevin daha çocukken onunla şiddet yüklü bilgisayar oyunları oynar. Babanın olan biteni görmediğini, Eva, ikinci çocuğu Celia'ya (Ashley Gerasimovich) hamile kaldığında onun büyüyen karnını ilk fark edenin Franklin değil, Kevin olması da ima eder.

Teb Kralı'nın oğlu Oedipus bilmeden hem babası Laios'u öldürür hem de annesi lokaste'yle evlenir (Green, 2004: 31). Bu mitsel anlatıya dayanarak Freud (1998: 345) şunu saptar: "illk cinsel dürtülerimizi annemize, ilk nefretimizi ve ilk cinayet arzumuzu babamıza karşı hissetmemiz belki de hepimizin kaderidir".

\section{Psikanalitik Perspektiften Kevin ve Eva İlişkisi}

Film boyunca bazı sahnelerde tekrarlanan su metaforuyla Eva'nın yüzünün Kevin'a, Kevin'in yüzünün Eva'ya dönüşmesi, anne-oğul arasındaki duygusal bağı olduğu kadar bu bağın kırılganlığını da gösterir. Baba işlevinin eksikliği Kevin'in anneden ayrılmasında ve simgesel düzene geçmesinde sorunlar yaşanmasına yol açmış gibidir: "Psikanalitik modele göre erkek çocuklar, birer erkek olabilmek adına, anneden kopmayı öğrenmelidirler; erkek çocuk anneden kopuşu kabullenmelidir" (Ryan ve Lenos 2012: 239). Kevin'in çocukluğunun farklı dönemlerinde simgesel düzene geçiş sorunları söz konusudur: Kevin konuşabildiği halde konuşmayı reddeder; tuvalet eğitimini kabul etmekte zorlandığı gibi oyun oynamaktan yana da değildir. Filmde annesinin sevdiğini var saydığı çalışma odasının duvarını kırmızıya boyaması, kendini tatmin ederken onu yakalayan annesine karşı utanç duymaması da toplumsallaşmaya ve dolayısıyla büyümeye karşı direnişinin işaretleri olarak verilmektedir. Dahası anne ve babasının boşanacağı haberine Kevin, çok daha saldırgan bir tutumla karşıık verecek; kız kardeşi ve babasını öldürecektir.

Psikanalitik kurama göre 3-5 yaş arası dönemde insanın toplumsal bir varlık olarak ait olduğu soyun uzantısı olmasını; ait olduğu cinsiyetin farkına varmasını ve zamanla bir kimlik geliştirmesini sağlayan, insancıllaştırıcı, ama aynı zamanda dramatik olan bir süreç vardır: "Oedipal Karmaşa". Bu süreçte baba, Yasa'nın sözcüsü olarak çocuk ile anne arasına girerek çocuğa Yasa'yı dillendirir ve onu 
geçerli kılar. Bu devrede çocuk artık yoğun olarak annenin bakımında değildir. Annesiyle arasında bir dizi dolayım söz konusudur ve bu dolayımlardan en temel olanı da "dil"dir. Dili öğrenen çocuk artık isteklerini ve duygularını ağlayarak ya da bağırarak anlatmaya çalışmaz, dile getirir, yani annesine başvurmak için bir dolayımı devreye sokar. Ve bu dolayım, çocuğun toplumsallaşmasının ön koşuludur (Habip 2007: 81, 82). Ayrıca dili öğrenme nörolojik olgunluğun artmasının yanı sıra, bebeğin kurduğu özdeşleşmelerle benliği zenginleştikçe, dil gibi daha karmaşık becerileri edinmesi sayesinde olur. Çocuğun simgesel aşamaya geçerek toplumsala dahil olması için dil, önemli bir etkendir; çünkü özne-ben'in kuruluşunda dilin varlığı mutlaktır (Bakır 2008: 27). Kevin'ın ise herhangi bir fiziksel, zihinsel engeli olmadığı halde dili öğrenmeyi, dili öğrenmiş olsa da uzun bir süre annesiyle dile başvurarak iletişime geçmeyi reddetmesi, benlik gelişiminin ve toplumsallaşmanın düzgün bir biçimde sağlanmadığını düşündürtmektedir. Bir sahnede Eva Kevin'i konuşturmaya çalışırken çocuğun oynadığı oyuncakla gürültülü sesler çıkararak annesinin sesini bastırması, başka bir sahnede Kevin'a "anne" dedirtmeye çalışan Eva'nın çabasının sonuçsuz kalması ve Kevin'in "anne" yerine "hayır" demesi, 5-6 yaşına geldiğinde Kevin'in hâlâ sınırlı bir biçimde konuşması yüzünden çocuğu doktora götüren Eva'ya doktorun çocuğun konuşmasını engelleyecek herhangi bir rahatsızığı olmadığını söylemesi Kevin'in benliğini geliştirmede ve toplumsala uyum sağlamada sıkıntılar yaşadığını göstermektedir. Buna ek olarak kişinin iradi kontrolünü mümkün kılan nörolojik olgunlaşma ile gerçekleşen ve benlik işlevlerinin gelişimiyle yakından ilgili olan tuvalet terbiyesini (Akvardar vd 2010: 67-69) de Kevin'ın uzun yıllar geliştirememesi, çocuğun annesiyle olan bağının kırılganlığının bir işareti olarak okunabilir.

Üstbenliğin oluşumunda etkin olan özdeşleşme mekanizması ile çocuk Oedipus karmaşasından çıkarken ebeveynlerine yönelttiği libidoyu da geri çeker ve nesnelerinin kaybını telafi etmek için bu nesne/nesnelerle yoğun bir özdeşleşme kurarak onları kendi benliğinin içine, benliği denetleyen bir mekanizma olarak yerleştirir. Bu, Freud'da Oedipus karmaşasının çözülümü ve üstbenin kurulması anlamına gelir. Bu karmaşanın aşılmasının tam olmadığı durumlarda, aynı zamanda büyüme ve olgunlaşma anlamına gelen üstbenlik gelişimi sonlandırımamıştır (Bakır 2008: 27). Annenin ilk arzu nesnesi, babanın ise toplumsalın -yani yasanın- taşıyıcısı olarak görüldüğü Oedipal karmaşada anne, çocuk için, özellikle de erkek çocuk için, önemli bir yere sahiptir. Çünkü "yalnızca hayatta kalmayı sağlayan gereksinimler değil, aynı zamanda mimetik ilk eğilimler de anneye doğru yöneltilir. Anne, öteki nesnedir, benim özne varlığımı garanti eden bir nesnedir. Anne, arzulanan ve anlamlandırılabilir ilk nesnemdir" (Kristeva 2004: 53).

Freud, Oedipal karmaşada bir korkuyu da dile getirir. Bu, Oedipus'un içerdiği ve çocuğun simgesele ve toplumsala uyumunu sağlayan bir korkudur: Hadım/iğdiş edilme korkusu. Hadım edilme korkusu, Oedipal karmaşanın bir parçasıdır ve onun içinde yer alır (Green 2004: 31). Başlangıçta kendi cinsel 
organının herkeste bulunduğuna inanan erkek çocuk, annenin ya da başka bir öteki cinsin cinsel organını gördügüünde açmaza düşer, annede eksik olan penisin yokluğundan kendi cinsel organını, üstelik babanın eliyle kaybetmekten korku duyar. Anneyle olası her türlü birleşmeyi yasaklayan hadım edilme tehdidiyle erkek çocuk, anneye duyduğu arzudan vazgeçerek babayla özdeşleşmeyi seçer, yani yasaya boyun eğer. Erkek çocuğun anneye olan simgesel cinsel yönelimini, babanın yine simgesel düzlemde yasaklaması, çocuğun anneye duyduğu arzunun hadım edilme tehdidi (babadan duyulan korku) nedeniyle baskılanmasına sebep olur. Erkek çocuk, babadan korkmakla birlikte aynı zamanda o, hayran olduğu bir şeye, fallusa sahip olan kişidir (Freud, 2002: 181).

Oedipus karmaşasında erkek çocuk için dişi figürün taşıdığı anlam, psikanalitik açıdan derin bir problemi imler. 1970'lerdeki ses getiren çalışması "Görsel Haz ve Anlatı Sineması"nda (Visual Pleasure and Narrative Cinema) bu durumu dile getiren feminist kuramcı Laura Mulvey'e göre, bakışın sürekli etrafında dönüp durduğu ama yadsıdığı bir şey vardır: Dişi figür, penis yoksunluğuyla hadım edilme korkusunu sezdirdiğinden ötürü hoşnutsuzluk verir. "Sonuçta kadının anlamı, hadım edilme kompleksinin üzerine temellendiği maddi delil olan penisin yokluğu, yani cinsel farklılıktır... kadın, bu yüzden, her zaman özünde işaret ettiği endişeyi uyandırmakla tehdit edicidir" (https://www. amherst.edu). Cinsiyet farklılığ bilinci geliştirmesine yarayan bu korkuyla erkek çocuk, böylece kadını tehditle bir tutarken; cezanın uygulayıcısı olarak babayı, yani erkeği görür (Green 2004: 14).

Oedipus karmaşasıyla ilgili önemli olan bir olgu da çocuk tarafından bizzat gözlemlenen ya da gözlemlenmese de düşlenen, anne ve baba arasındaki cinsel ilişki sahnesidir. Psikanalizde "ilk sahne" olarak adlandırılan ve çocuk tarafından babanın uyguladığı bir şiddet edimi olarak yorumlanan ilk sahne, travmatik bir deneyimdir. Anne babanın cinsel ilişkisine gerçeklikte tanık olmak, çocukta yıkıcı etkiler yaratabilir ve patolojik sonuçlara yol açabilir. IIlk sahneye kritik yaşlarda ve/veya yoğun biçimde maruz kalmak, bir yandan ruhsal örgütlenmenin sağlıklı gelişimini tehdit ettiği gibi bir yandan da anne ve babasının ilgisinin merkezinde iken bu ayrıcalıklı yeri kaybettiğini hisseden çocuğun kendi güçsüzlüğüyle yüz yüze gelmesine ve büyük bir narsistik yaralanma yaşamasına neden olur. Illk sahne çocukta haset, kıskançlık, suçluluk ve saldırganlık duyguları uyandırır (Erdem 2011: 115-121). Bu açıklamalar film açısından düşünüldüğünde ise Kevin'in 6-7 yaşlarındayken annesinin, babasına oral seks yaptığını görmesinin, onun yaşamakta olduğu çatışmaları artırıp travmatik bir etkiye yol açmış olabileceği, kritik bir yaşta tanık olduğu bu ilk sahne deneyiminin ondaki saldırganlık ve şiddet eğilimini arttırmış olabileceği öne sürülebilir.

Annenin, bebeğin gerilimlerini, gereksinimlerini gideren, onu koruyan en başat doyum kaynağı olduğu varsayımından hareketle Eva'nın, sürekli ağlayan huzursuz çocuğu Kevin'ın gerilimlerini bastırmakta zorlandığı görülür. Doğduğunda Kevin babanın kucağında sakinleştirilmeye çalışılırken Eva, 
hastanedeki yatağında yanında ağlayan çocuğundan uzak, boş ve sabit gözlerle karşıya bakmaktadır. Hastaneden eve geldiklerinde de durum değişmez: Kevin, sürekli ağlarken Eva, onu yatıştırmakta güçlük çekmektedir. Bebeğini, sakinleştirmeye çalışırken onu kendinden uzakta tutarak bebekle olan fiziksel temasını sınırlandırması ve hoşnutsuz bir şekilde dudaklarını ısırması, ilerleyen yıllarda yeni evlerine taşındıklarında boş evde Eva ve Kevin'in, aynı çerçeve içinde ancak sırtları dönük ve birbirlerinden uzak konumlanmaları gibi sahneler, anneçocuk arasındaki mesafenin sadece fiziksel olmaktan öte, duygusal bir boyutunun da olabileceğini düşündürür.

\section{Fotoğraf 4-5-6: Eva ve Kevin}
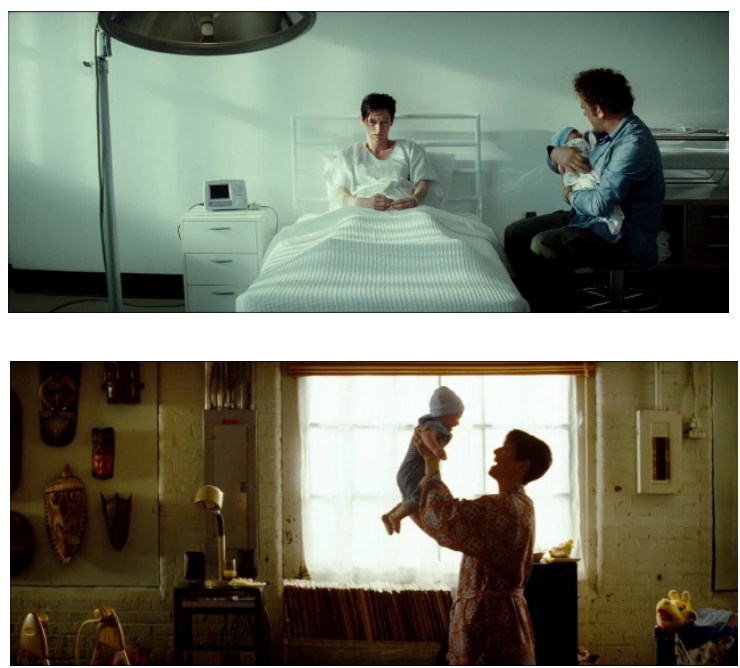

Psikanalizde çocuğun ilk nesne ilişkisinin, beslenme ihtiyacının karşılanmasına dönük oral ve yaşamsal bir ilişki olduğu belirtilir. Nesneye bağlanmanın ilk özgün örneği, çocuğun kendisini besleyen, bakan ve koruyan anneye bağlanmadır ve buna "anaklitik türde bağlanma" denir. Bağlanma ve sevgi nesnesi olarak anne, birkaç dürtünün doyumuna hizmet edebilir (Akvardar vd 2010: 90-93). Eva'nın Kevin'le ilişki kurmakta yaşadığı zorluk, Kevin'da bir eksiklik/yoksunluk duygusuna yol açmış gibi görünmektedir. Kristeva'ya göre yoksunluk deneyimi ile saldırganlık, mantıksal olarak birbirine bağlanabilir olur. "Saldırganlığın 'ilk narsisizm' denilen seraptan itibaren duyumsanan ilk yoksunluğa verilen bir karşılık olduğu kanısındayız, saldırganlık ilk yoksunluklardan intikam almaktan başka bir şey yapmamaktadır. Eksiklik ve saldırganlık arasındaki ilişki hakkında bilebildiğimiz şey, her ikisinin de birbirinin eşdeğeri olduğudur" (Kristeva 2004: 61).

Burada çocuğun nesne sevgisinin yanı sıra kadınların "tam nesne sevgisi"nden de söz etmek gerekir. Kadınların "doğurdukları, yani kendi 
bedenlerinden çıkmış olan çocuğu, dışarıdaki bir nesne olarak, tam bir nesne sevgisi ile sevebilmeleri" (Akvardar vd 2010: 92) anlamına gelen bu sevginin oluşumunda Eva'nın zorlandığını söylemek mümkündür. Bu durum üzerinde, Eva'nın doğurduğu çocuğu kendi dışında bir nesne olarak görememesi yani onunla bütünlük arzusunun sonlanmaması etkili olabileceği gibi; Kevin'la Eva arasında istenilen yakınlığın kurulamaması da etken olmuş olabilir. Bu durumun filmdeki en somut kanıtlarından biri, ikinci çocuğuna hamile olan Eva'nın Kevin'a bir kardeşi olacağını açıklamaya çalıştığı sahnede, anne ve oğul arasında geçen şu diyalogda kendini gösterir:

- Eva: "Kardeşine zamanla alışırsın".

- Kevin: "Bir şeye alışkın olman ondan hoşlanıyorsun anlamına gelmez. Sen de bana alışkınsın".

- Eva: "Peki, o zaman birkaç ay sonra yeni birine daha alışmak zorundayız".1

Annesinin bu cevabı karşısında Kevin elindeki boya kalemini hırsla kırar. Annenin doğurduğu çocuğu sevmekle yükümlü olduğu yönündeki geleneksel anlatının yıkılması filmdeki başka bir sahnede ise şöyle gerçekleşir: Kevin'i sakinleştiremeyen Eva en sonunda sabrı tükenmiş bir halde oğluna şöyle seslenir:

- Eva: "Küçük Kevin gelince anne çok mutlu olmuştu biliyor musun? Ama şimdi anne her sabah uyandığında keşke Fransa'da kalsaydım diyor".

Kevin doğduğunda ya da daha önce, hamilelik sürecinde de Eva mutlu görünmez. Hamileyken büyüyen karnına ve Franklin'in aldığı çocuk salıncağına yabancı gözlerle bakar, katıldığı hamilelik kursunda diğer anneler karınları açık bir şekilde giyinmiş ve hallerinden hoşnut bir şekilde gebelikleri hakkında konuşurken, Eva karnını tamamen kapatan bir kıyafet giver, doğumunu çığlık seslerinin eşlik ettiği bulanık görüntüler olarak hatırlar, sürekli ağlayan Kevin'ı susturamayıp da dışarı çıkardığında çocuğunun sesine iş makinalarınınkini tercih eder. Böylelikle Eva'nın anneliğe gerçekten hazır olup olmadığı film boyunca sorgulanır.

\section{Krizi}

\section{Toplumsal Cinsiyet Kabullerinde Kadınlığın İnşası: Eva'nın Annelik}

Film anneliğin, güdüsel mi yoksa toplumsal cinsiyet rolleri içerisinde dayatılmış ve öğrenilen, verili bir olgu mu olduğunu da tartışmaya açmaktadır. Bu bağlamda Butler'ın "Toplumsal cinsiyet inşa edilmiş bir şeyse eğer, farklı bir şekilde inşa edilebilir mi?" (2010: 27) sorusundan yola çıkılarak toplumsal cinsiyet kalıpları içinde şekillenen anneliğin de farklı bir biçimde inşa edilip edilemeyeceği sorulabilir.

1 Vurgu, yazarlara ait. 
Cinsiyet terimi, kadın ya da erkek olmanın biyolojik yönünü ifade etmekte ve bu doğrultuda bireyin biyolojik cinsiyeti bağlamında belirlenen demografik bir kategori oluşturmakta iken; toplumsal cinsiyet kadın ya da erkek olmaya toplumun ve kültürün yüklediği anlamlarla beklentileri ifade etmektedir (Bayhan 2013: 153). Toplumsal cinsiyet, tanımdan da anlaşılacağı üzere toplumsal ve kültürel olarak inşa edilir. Dolayısıyla verili toplumsal cinsiyet kabullerinde kadın ve erkek arasında kaçınılmaz olarak var olduğu kabul edilen farklılıklar, doğal değildir, oluşturulmuştur. Bu bağlamda toplumsal cinsiyet, erkeklerin ve kadınların birbirlerinden farklı olmalarına yol açan fiziksel niteliklere değil, erkeklik ve kadınlık hakkındaki toplum tarafından oluşturulmuş özelliklere göndermede bulunmaktadır (Giddens'tan akt. Bayhan 2013: 155).

\begin{abstract}
"Kültürel olarak insanlara cinsiyet atama çabasının en büyük gayesi, ilişkilerin ve farklılaşmaların -ontoloji ya da tabiat içinde sağlam temellere sahip doğal bir sürecin yansıması ya da ifadesi gibi görünen ve varsayımsal olarak başkasına intiyaç duymayan bütünlere (tam kapalı kutular gibi)- dönüştürülmesi vasıtasıyla toplumsal cinsiyet kimliğinin üretimini gerçekleştirmektedir. Yani bir fabrika (yapay) sanki bir madenmiş (doğal) gibi görünmek zorundadır" (Ryan ve Lenos 2012: 232).
\end{abstract}

Butler (2010: 27), "toplumsal cinsiyet alanının betimlemesi hiçbir surette onun normatif işleyişinden önce gelmez ve ondan ayrı tutulamaz" derken, öncelikle toplumsal cinsiyeti kader haline getiren hiçbir sabit kategoriden söz edilemeyeceğini, toplumsal cinsiyet inşasının, beden, cinsiyet ve kimlik kategorilerine sabitleyen iktidar ilişkilerinin normatif işleyişi içerisinde gerçekleştiğini vurgulamaktadır (Arpacı 2013: 131).

Film ataerkil düşünce içerisinde şekillenen verili annelik pratiklerinin kadının doğal ve güdüsel olarak istediği bir durum değil de toplumsal cinsiyet rollerinin dayattığı yükümlülükler olduğunu ve her kadının buna hazır olmayabileceğini, kendinden istenilenleri yerine getiremeyebileceğini vurgular. Üstelik bunu yaparken film, izleyiciyi Eva'yı anlamaya zorlamakta ve sorgulanması gerekenin Eva ya da Eva'nın anneliği değil, toplumsal cinsiyet kabulleri olduğuna işaret etmektedir. Bunun göstergelerinden biri olan toplumsalın dayattığı zorunluluklardan kaçış isteği, Eva'yla bağlantılandırılarak filmin birçok yerinde simgelerle kendini göstermektedir. Filmde sıkıkla karşımıza çıkan ve bir şekilde Eva ile ilişkili olan Escape (Kaçış) yazısı (Eva'nın çalıştığı şirketin adı olarak, afişlerin, bilgisayar ekranının üzerinde, Eva'nın yazdığı seyahat kitabının imza günüyle ilgili afişin asıldığı duvarda vb.) Eva'nın Kevin'dan yani "annelik"ten önceki hayatına kaçma, sığınma özleminin bir dışavurumu olarak yer alır.

Kevin'a iyi geleceği düşüncesiyle, Eva istemediği halde, Franklin'in satın aldığı ve taşınırlarken "İşte bizim kalemiz" dediği banliyödeki evin anlamı, Eva için çok farklıdır. Ya da Franklin'in olumlar şekilde söylediğinin aksine ev, Eva için de bir kaledir; ama onu koruyan ve barınmasını sağlayan bir yer olmaktan öte, onda sıkışmışlık hissi uyandıran ve kaçmanın bir türlü mümkün olmadığı bir kale. Bu 
doğrultuda Eva'nın anılarında ev ya da evle ilgili her şey sıkıntı verici, kısıtlayıcı ve kırmızı bir tona sahipken; katliamdan sonra iş başvurusu için gittiği ofiste Eva'nın önünde oturduğu afişteki yazının da (Puerto Rico is calling you home- Porto Riko sizi eve çağırıyor) gösterdiği gibi Eva'nın evi, bulunduğu yer değil kaçmak istediği yerdir, eski gezgin yaşamıdır. Katliamdan sonra Eva'nın gittiği çorbacının kırmızı tabelasının üzerindeki "Home Style" (Ev Yapımı) yazısı da onun bir yandan belki Franklin'in bahsettiği gibi sıcak bir eve duyduğu özlemi yansıtırken; bir yandan yine evi anımsatan her şeyin zihninde ve ruhunda kırmızıyla ilişkilendirildiğini göstermektedir.

Geleneksel anlatılarda evi, dört duvar olmaktan çıkarıp ona yuva özelliği kattığı söylenen aile de filmdeki önemli kilit noktalardan biridir. Franklin de dahil olmak üzere neredeyse filmin tüm ana karakterleri, aile kurumunda kendilerine biçilen görevler ve kendilerinden beklenen sorumluluklarla ilgili sıkıntılar yaşamaktadır. Bu sıkıntıların çözümsüzlüğünün vardığı son nokta ise Franklin ve Eva'nın aldığı boşanma kararı olur.

Annelikle ilgili yaşadığı tüm sıkıntılara rağmen Eva'nın, film boyunca Kevin'la iletişim kurmaya ve onunla yakınlaşmaya çabaladığı görülmektedir. Kevin'la top oynamaya ve ona sayıları öğretmeye çalışması, hastalandığında endişelenip şefkatli bir şekilde onunla ilgilenmesi, Kevin genç bir delikanlı olduğunda onunla vakit geçirmeye çalışması, Kevin'ı imza günüyle ilgili afişin önünde gördüğünde mutluluk duyması, Kevin'ın doğum günü kutlaması için plan yapması gibi unsurlar film boyunca Eva'nın Kevin'la yakınlaşma çabaları olarak kendini gösterir. Ayrıca Eva'nın, katliamdan sonra yaşadığı tüm zorluklara ve toplumsal baskılara rağmen oturduğu semti terk etmemesi, hapishanedeki Kevin'ı görmeye gitmesi, yeni evini Kevin'ın hapishaneden çıkacağı gün için hazırlaması, Kevin'ın odasını eski evdekiyle aynı şekilde dizayn etmesi, onun kıyafetlerini koklayarak ağlaması Kevin'a olan bağlıığını simgelerken; ondan ayrılmakta ne kadar zorlandığına da işaret etmektedir.

\footnotetext{
“Erkeklerin de yaşadığı bir olgu olan ayrılık anneler için özellikle çocuklardan ayrılmak söz konusu olduğunda erkeklerinkinden daha acılı ve sancılı bir deneyim olmaktadır. Kadınların bu deneyimi, kendini öteki'ye verme, adama ya da kurban etme gibi deneyimlerle eşdeğer olarak görülmektedir. Bu anneliğe özgü ötekiyle bağlantı, yani kendini ötekiye adayarak onu kendi dışında bağımsız bir varlığa dönüştürme deneyimi annenin yüceltilmesinin de nedenini oluşturur. Bu kendinde önemli bir deneyimdir" (Tutal Cheviron 2010: 116).
}

Hapishanedeki Kevin'ı ziyarete gittiğinde güvenlik kontrolünden geçerken Eva'nın bedeninin yarısının kapının ardında, yarısının dışında konumlanması da Eva'nın bir yanının Kevin'la birlikte, "içeride” olduğunu imlemektedir. 
Fotoğraf 7: Hapishanenin güvenlik kontrolünden geçen Eva

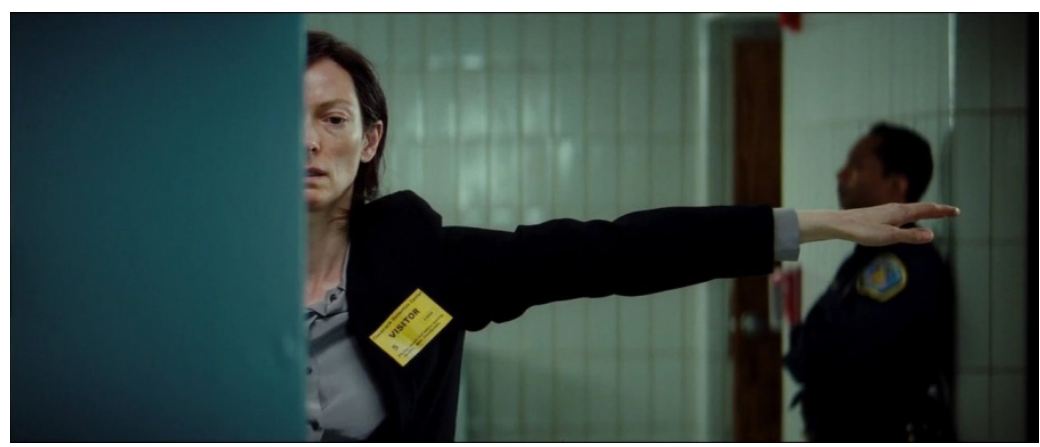

Hapishanede Kevin'ı ziyarete gittiğinde karşısında oturan oğlunun kopardığı tırnakları ağzından çıkarıp masanın üzerine koyduğunu gören Eva'nın, akşam evde, marketten aldığı kırık yumurtalardan yaptığı omleti yerken; omletten çıkan yumurta kabuğu parçalarını tıpkı hapisteki Kevin gibi, ağzından çıkarıp masanın üzerine koyması da bize Eva'nın, Kevin'ın suçunun en azından yarısını üstlendiğini gösterdiği gibi, koşulsuz bir adanmışlıkla kendini ona verdiğini, hatta kendisini onunla bir gördügünü de kanıtlar gibidir.

Film boyunca, Eva'nın oğluyla tüm yakınlaşma girişimlerinin Kevin tarafından sürekli olarak geri püskürtüldügünü görürüz. Ancak Kevin'ın, Eva'nın onunla kendince sağlıklı bir biçimde kurmaya çalıştığı ilişkiyi imkânsız hale getirdiğini söylemek mümkün olsa da bir yandan da Eva'ya derinden bağlı olduğunu, ondan ayrı düşmek istemediğini de belirtmek gerekir. Belki de Kevin, kendisinin kötü olduğunu düşündüğü için, ne kadar uzak görünseler de aslında kendine en yakın kişi olarak annesini görmektedir. Hatta bu durum birlikte golf oynamaya giden anne oğul arasındaki bir konuşmada belirgin şekilde kendini gösterir. Golf sahasında Eva'nın kilolu insanlar için söylediği acımasız sözler karşısında Kevin'ın Eva'ya söyledikleri bu noktada anlam kazanır.

- Kevin: "Bazen çok sert oluyorsun".

- Eva: "Sert mi? Bunu sen mi söylüyorsun?"

- Kevin: "Evet, ben. Kime çekmişim acaba?"

Bu konuşmadan da anlaşılacağı gibi Kevin, her ne kadar annesinin çabalarını reddeder gibi görünse de gerçek anlamda ve samimi olarak iletişim kurduğu tek kişi annesidir. Babasıyla olan ilişkisindeki iyi ve sorunsuz hali ise, onun oynadığı kurmaca bir oyundan ibarettir. Çocukken hastalandığında annesinin sevgi ve ilgisini istemesi, o sırada yanına gelen babayı uzaklaştırması, o gün ilk kez annenin omzuna başını koyup ona çok sevdiği Robin Hood kitabını okutturması, Eva'nın onu öpmesine ve saçını okşamasına izin vermesi Kevin'ın film anlatısı 
içinde annesine en yakın olduğu zamandır. Ancak ertesi gün Kevin iyileştiğinde Eva, onunla yine olumlu bir şekilde iletişime geçmeye çalıştığında, annesine karşı eski sert tavrına geri döner. Çünkü Kevin için annesiyle kurduğu ilişkideki dürüst ve samimi davranış biçimi belki budur ve annesinden de bunu bekler: Hissettiği gibi davranmasını...

Kevin'ın, kolunun yaralanmasında annesinin sorumluluğuyla ilgili ne hastanede doktorlara ne de babası Franklin'e bir şey söylemesi, çocuğun annesiyle arasında bir sır oluşturarak onunla kendince bir bağ, bir iliş̧i kurma çabası olarak yorumlanabileceği gibi anneyi, kendisine borçlu bırakma isteği olarak da görülebilir. Zaten bir başka sahnede arabada giderlerken Eva, Kevin'a markete uğrayıp bir şeyler almaları gerektiğini söylediğinde Kevin'ın markete değil, eve gitmek istediğini kolundaki yaraya dokunarak söylemesi de çocuğun bu sırrı, annesiyle olan savaşında bir silah olarak kullandığını gösterir. Kevin'la Eva arasındaki ilişkinin Kevin tarafından bir savaş olarak kodlandığının tek göstergesi bu değildir. Bu savaş, Kevin'la Eva golf oynamaya gittikleri zaman oyunun sonunda Eva'nın ona "Sen kazandın" demesi üzerine, bir başka sahnede Kevin'ın buna verdiği cevapla iyice belirginleşir. Söz konusu sahnede oğlunun uyuşturucu kullandığından şüphelendiği için Kevin'ın odasını arayan Eva, üzerinde / Love You (Seni Seviyorum) yazan bir cd bulur. Cd'yi kendi bilgisayarına taktığında bunun Kevin tarafından, Eva'nın bulması için hazırlanmış ve bilgisayarı çökertecek virüs taşıyan bir tuzak olduğu anlaşıır. Cd'de gülen bir palyaçonun bulanık görüntüsünün üzerine düşen "You lose" (Kaybettin) yazısıyla Kevin kendi zaferini ilan eder. Bu, aynı zamanda Eva'nın bu savaşın yanı sıra her şeyini kaybedeceğini işaret eden bir gösterge olarak okunabilir.

Kevin'ın bütün eylemlerini anneye yönelik olarak gerçekleştirmesi, hem bu savaşın bir parçası hem de kimi zaman anneden ayrılmak istemeyişin bir kanıtı olarak ortaya çıkar. Kız kardeşi doğduğunda Eva'nın ona sevgiyle baktığını gören Kevin, bebeğin yüzüne su sıçratır, anne ve babasının boşanma kararı aldıklarını tesadüfen öğrendiğinde anneden ayrılma intimalinin korkunçluğu karşısında katliam planını devreye sokar. Tüm bunlar, Kevin'ın Eva için tek olma isteğinin göstergeleri olabilir. Kevin'ın çocukken babası Franklin'in ona aldığı ok takımıyla bahçede atış yaparken bir anda hedef tahtasının tersi yöne dönüp annesinin bulunduğu odanın camına oku fırlatması da tüm edimlerini anneye dönük gerçekleştirdiğini gösteren diğer bir göstergedir. Kimyasal bir maddeyi bilerek açıkta bırakarak kız kardeşi Celia'nın bir gözünü kaybetmesine neden olduğunda, olayı Eva'nın suçlanacağı şekilde tasarlaması, hatta katliam günü polis arabasına bindirildiğinde arabanın arka camından dönüp Eva'ya bakması da tüm davranışlarının temelinde annesiyle ilgili bir problemin varlığını hissettirmektedir.

Kevin'ın aslında annesine yönelik olarak gerçekleştirdiği katliamla, babası Franklin ve kız kardeşi Celia başta olmak üzere, okuduğu lisedeki birçok kişinin de ölümüne yol açan şiddet dürtüsü ve katliamla ilgili ipuçları, film boyunca birçok yerde verilmektedir. Örneğin film, olayın failini açıkça göstermese de Kevin, 
kız kardeşinin çok sevdiği hamsterını çöp öğütücüsüne atarak öldürür, Noel yaklaşırken koltuğun üzerinde tabutta yatan birini anımsatır şekilde kız kardeşi Celia'nın ellerini kollarını bağlar, Celia'nın bir gözünü kaybetmesine "isteyerek" sebep olur. Kevin, anne babasının boşanma kararını öğrendikten sonra katliamda kullanacağı bisiklet kilitlerini sipariş eder, katliam günü evde Franklin ve Celia dans ederken onları izler ve hırsla nefes alıp verir, katliamın gerçekleşeceği günün sabahı ateşi olduğunu fark eden Eva ona iyi olup olmadığını sorduğunda "Hiç bu kadar iyi olmamıştım" yanıtını verir. Tüm bu sahnelerdeki göstergelerin yanı sıra 16. yaş günü yaklaşırken, doğum gününde Kevin'a birlikte bir şeyler yapmayı teklif eden Eva'ya, Kevin'ın "Bilmem, belki o gün etrafı toparlarım" demesi de, katliamın habercileri olarak film anlatısı içinde yer alır.

Katliam günüyle ilgili eklenebilecek önemli bir nokta da Kevin'ın, kendi "tamlığına" erişeceğini düşündüğü bu eylemi, bir gösteriye dönüştürerek gerçekleştirmesidir². Olayın gerçekleştiği okulun spor salonunda elindeki ok ve yayla, asıında olmayan bir seyirciye selam vermesi, polisler onu dışarı çıkarırken onu bekleyen kameralar ile insanlara kendinden emin bir şekilde bakması Kevin'ın yaptığı eylemi sansasyonel bir gösteri olarak kurguladığını ve algıladığını göstermektedir 3 .

\section{Fotoğraf 8: Hayali seyircisine selam veren Kevin}

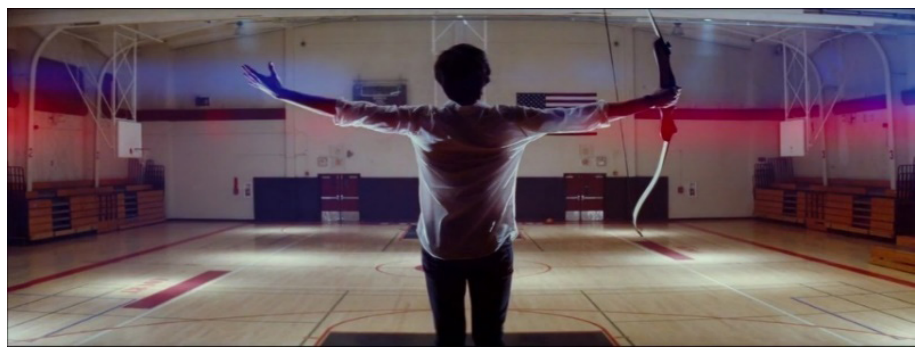

Kevin'ın faili olduğu gösterisel katliamın, onun kendini gerçekleştirme çabası olduğu Kevin'la ilgili fiziksel gösterenlerde belirginleşir. Katliam gününe kadar bedenine dar gelen çocukluk tişörtlerinden vazgeçemezken; o gün belirgin bir şekilde kendi yaşına uygun kıyafetler giymeyi tercih etmesi, o ana kadarki

2 Bu noktada Guy Debord'un "gösteri toplumu" tezini anımsamak gerekir. Modern dünyada gösteri, insanın çok fazla seyirci kalmasından ileri gelirken; modern insan her yerde her türden insanın beklenmedik şekilde öldürüldüğünü görmeye uzun zamandan beri alışmıştır (Debord 2012: 148, 209). " ...yaşam deneyiminde modern insan belki acı çeker ama pişmanlık ve vicdan azabı duymaz. İmgelere boğulur, imgeler onun yerine geçer. Yaşadığı hayal aleminde gösteriden o da bir pay almaya çalışır. (...) Kristeva, ruhun yeni hastalıklarının tanısını burada koyar: Özne için temsilleri ve anlamsal değerleri kaybeden aygıt ruh, yani psişik aygıt bozulmuştur, çalışmamaktadır" (Tutal 2011: 228).

3 Hapishanede kendisini ziyarete gelen Eva'ya, Kevin'in söyledikleri anlamlıdır. Kevin: "insanların hayatının yarısının televizyon ile geçmesi ne kadar kötü. Televizyondalar ya da televizyon seyrediyorlar. Tüm bu insanlar kimleri seyrediyor? Benim gibileri". 
eksiklik duygusundan kurtulup tamamlanmış hissetmesiyle, kendince bir benlik oluşturduğunu düşünmesiyle bağlantılandırılabilir. Ancak bu tamamlanmışlık hissinin uzun sürmediği, filmin final sahnesi olan Kevin ve Eva'nın hapishanede, katliamın ikinci yıldönümündeki son karşılaşmalarında kendini gösterir.

- Eva: "Mutlu görünmüyorsun."

- Kevin: "Daha önce mutlu muydum ki?"

- Eva: "iki yıl geçti ve düşünmek için çok fırsatın oldu. (...) Neden?"

- Kevin: "Bildiğimi sanıyordum ama şimdi o kadar emin değilim."

Bu cevap üzerine Eva, ilk kez Kevin'a güçlü bir şekilde sarılır. Bu sahne bize Eva'nın hem kendini hem Kevin'ı affettiğini gösterirken; film anlatısı içinde anne ile oğlun ikinci olarak en yakın olduğu an olur. O gün Kevin'ı görmeye gitmeden önce Eva'nın film boyunca evinden ve aslında hayatından çıkarmaya çalıştığı kırmızı boyaların tamamen temizlenmiş olması, uzun zamandır düzenlediği Kevin'ın odasındaki hazırlıkların tamamlanması, Eva'nın ilk kez o gün Kevin'ın kıyafetlerini koklayarak ağlaması, yaşadığı duygusal arınmaya işaret etmektedir. Hapishanede Kevin'la ve de kendiyle hesaplaştıktan sonra filmin, hapishaneden dışarıdaki aydınlığa çıkan Eva'nın görüntüsüyle bitmesi ise Eva'nın, Kevin'ı da bırakmadığı yeni hayatına başlamaya artık hazır olduğunu ve kendi hapishanesinden kurtulduğunu göstermektedir.

\section{Sonuç}

Kevin Hakkında Konuşmalııız, anlatı yapısının kuruluşu ve olayları ana kadın karakter olan Eva'nın bakış açısından izlettirmesiyle ana akım sinemanın erkek bakışlı egemen uylaşımlarının karşısında konumlanmaktadır. Bu bağlamda film anlatısı, toplumsal cinsiyet kabulleri ve bunlar içerisinde kadına anne olarak biçilen rolleri, ana akım sinemadakinin aksine destekleyici değil, sorgulayıcı nitelikte işlemektedir.

Film, Eva'nın ev-aile-çocuk üçgeninde yaşadığı sıkıntıları ve sıkışmışlığı, kasvetli bir atmosfer içinde yansıtırken, Eva'dan yola çıkarak aslında modern toplumdaki kadını, kadının çaresizliklerini, çelişkilerini ve çatışmalarını anlatmaktadır. Kendi istekleri ve toplum tarafından dayatılan sorumluluklar arasında tercih yapmak zorunda bırakılan kadın, ne tam olarak istediği hayatı yaşamakta ne de reddedemediği toplumsal yükümlülükleri tam anlamıyla yerine getirebilmektedir. Bu da kadını, mutsuz kılmakta ve arada bırakmaktadır. Modern toplumun onayladığı ve beklediği annelik kalıpları içinde kendini konumlandıramayan Eva da toplumsal yükümlülüklerin baskısını hissetmekte ve kendisini de ister istemez bu çerçevede konumlandırmaya çalışmaktadır.

Çocuğunun işlediği bir suçtan dolayı toplum, anneyi suçlarken; toplumsal cinsiyet kabullerinin de etkisiyle anne de suçu üstlenmekte ve bedel ödemeyi kabul etmektedir. Bu bağlamda film, oğlunun işlediği katliamdan sonra Eva'nın, 
hem kendiyle hem de toplumla yaşadığı çatışmaları, kadının yanında yer alan ve onu anlamaya çalışan bir bakış açısıyla göstermektedir. Bir çocuğun toplum açısından tehlike oluşturan biri olmasının nedeni ister doğuştan gelen psikopatolojik bir rahatsızlık, isterse aile içerisindeki yaşantı olsun, film, kadını ne "fedakâr/kutsal anne" ne de "kötü/canavar anne" olarak konumlandırmaktadır.

$\mathrm{Bu}$ anlamda kadının yanında bir duruş sergileyen Kevin Hakkında Konuşmalıyız yapılandırımış erkeklik kalıplarına da eleştirel gözle bakmaktadır. Film boyunca Franklin'in çok az görünmesi, hatta bazen yalnızca bedensel bir figür olarak karşımıza çıkması, karısının hamile olduğunu ve çocuğunun şiddet eğilimini fark etmeyecek kadar ilgisiz biri olarak sunulması da bu eleştirel bakışın bir göstergesidir. Eva ile Kevin arasındaki sorunun çözümü için de gerçekçi bir seçenek sunmak yerine anneyi suçlamakta ve sonunda boşanmayı talep ederek kaçmak istemektedir. Tüm bunlara rağmen filmde hayati kararları alan da yine erkek (Franklin) iken, kadına (Eva) da istemese de bu kararları kabul etmek ve uygulamak düşmektedir. Ailenin devamı ve çocukların yetiştirilmesiyle ilgili neredeyse tüm sorumluluk kadının omuzlarına bindirilmekte, sorumluluklarının yükü altında ezildiğinde ise suçlanan ve yalnız bırakılan yine kadın olmaktadır.

Psikopatolojik bir rahatsızıkla doğmuş olabileceğini düşündürten Kevin'ın hâl ve davranışları, bebeklik yıllarında huzursuzlukla belirlenirken, annesiyle sağlıklı bir iletişim kuramaması ve kendi tamlığını oluşturamaması nedeniyle, zaman içerisinde daha saldırgan davranışlara evrilmiş olabilir. Ancak film, anne oğul arasında bu ilişkinin oluşamayışıyla ilgili olarak ne Eva'yı ne de Kevin'ı suçlamaktadır. Bu anlamda ana akım sinemadakinin aksine Kevin Hakkında Konuşmalıyız, bir suçlu ve/veya kahraman ilan etmez iken; toplumsal cinsiyet kabullerinin kadında yarattığı tahribatı, sorunlu bir anne-çocuk ilişkisi ekseninde eleştirel bir durum tespiti olarak ortaya koymaktadır. Bu noktada, toplumsal cinsiyetin inşa edilen bir olgu olduğu ön kabulünden yola çıkarak, başka alanlarda olabileceği gibi sinema alanında da, özellikle ana akım sinemanın dışında kalan filmler yoluyla bu kabullerin farklı bir biçimde ve daha eşitlikçi bir düzlemde yeniden kurulabileceği gerçeği ve umudu anlam kazanır.

Filmin uyarlandığı romanın ismi, Eva'nın Franklin'e yazdığı mektuplardan oluşması nedeniyle Kevin Hakkında Konuşmalıyız olarak seçilmiştir. Filmde ise bu isim, Eva'nın Franklin'e sessiz ve çaresiz seslenişi olarak yorumlanabileceği gibi, yönetmenin de toplumsal cinsiyet rolleri ve kadına yüklenen sorumluluklarla ilgili seyirciyi eleştirel düşünmeye ve sorumluluk almaya çağıran çabası olarak okunabilir. 


\section{Kaynakça}

AKŞiT VURAL Elif E. (2013), "Annelik, Feminizm, Tarih", Doğu Batı, Sayı: 64 (Şubat, Mart, Nisan), Ankara, Doğu Batı Yayınları, ss. 181-200.

AKVARDAR Yıldız, ÇALAK Erdoğan, ETANER Ulviye, HÜROL Cem, SUNAT Haluk, TÜKEL Raşit, ÜÇOK Alp ve YÜCEL Başak (2010), Psikanalitik Kurama Giriş, İstanbul, Bağlam Yayınları.

ARPACl Murat (2013), "Modernitenin Eşiğinde Toplumsal Cinsiyet Rejimi: Pastoral İktidar, Beden Politikaları ve Evlilik", Doğu Batı, Sayı: 63 (Kasım, Aralık, Ocak 2012-13), Ankara, Doğu Batı Yayınları, ss.131-146.

BAKIR Burak (2008), Sinema ve Psikanaliz, İstanbul, Hayalet Kitap.

BAYHAN Vehbi (2013), "Beden Sosyolojisi ve Toplumsal Cinsiyet", Doğu Batı, Sayı: 63 (Kasım, Aralık, Ocak 2012-13), Ankara, Doğu Batı Yayınları, ss.147-164.

BUTLER Judith (2010), Cinsiyet Belası, Çev. Başak Ertür, İstanbul, Metis Yayınları.

ÇELER Zafer (2013), "Annenin Serüveni: Kadının Anne Olarak Toplumsal Kurgulanışı", Doğu Batı, Sayı: 63 (Kasım, Aralık, Ocak 2012-13), Ankara, Doğu Batı Yayınları, ss.165-181.

DEBORD Guy (2012), Gösteri Toplumu, Çev. Ayşen Ekmekçi ve Okşan Taşkent, İstanbul, Ayrıntı Yayınları.

ERDEM Nilüfer (2011), “ilkk Sahne: Gerçek mi Düşlem mi?”, Doğu Batı, Sayı: 56 (Şubat, Mart, Nisan), Ankara, Doğu Batı Yayınları, ss. 115-125.

FREUD Sigmund (1998), Rüyaların Yorumu I, Çev. Selçuk Budak, Ankara, Öteki Yayınevi.

FREUD Sigmund (2002), Totem ve Tabu, Çev. K. Sahir Sel, İstanbul, Sosyal Yayınlar.

GREEN André (2004), Hadım Edilme Kompleksi, Çev. Levent Kayaalp, İstanbul, Metis Yayınları.

HABIP Bella (2007), Psikanalizin İçinden, İstanbul, Yapı Kredi Yayınları.

KABADAYI Lale (2014), Film Eleştirisi, İstanbul, Ayrıntı Yayınları.

KRISTEVA Julia (2004), Korkunun Güçleri, İğrençlik Üzerine Deneme, Çev. Nilgün Tutal, İstanbul, Ayrıntı Yayınları.

MULVEY Laura (t.y.), "Visual Pleasure and Narrative Cinema”, https://www. amherst.edu/system/files/media/1021/Laura \% 20Mulvey, \% 20Visual \% 20 Pleasure.pdf

PORTER Marie (2010), "Focus on Mothering", Hecate, Sayı: 36, Santa Lucia, Hecate Press, ss. 5-16. 
RYAN Michael ve LENOS Melissa (2012), Film Çözümlemesine Giriş, Çev. Emrah Suat Onat, Ankara, De ki Basım Yayım.

TUTAL CHEVIRON Nilgün (2010), "Cadılar da Sevimli Olabilir", Kadın ve Bedeni, Der. Yasemin İnceoğlu, Altan Kar, İstanbul, Ayrıntı Yayınları, ss. 93-129.

TUTAL Nilgün (2011), "Bu Epigrafı Bir Yazı Olacak", Doğu Batı, Sayı: 56 (Şubat, Mart, Nisan), Ankara, Doğu Batı Yayınları, ss. 217-237. 